\title{
Normative cruelties and gender deviants: the performative effects of bully discourses for girls and boys in school
}

\author{
Jessica Ringrose ${ }^{\mathrm{a}^{\star}}$ and Emma Renold ${ }^{\mathrm{b}}$ \\ ${ }^{a}$ Department of Educational Foundations and Policy Studies, Institute of Education, \\ University of London, London, UK; ${ }^{\mathrm{b}}$ Cardiff University School of Social Sciences, \\ Glamorgan Building, King Edward VII Avenue, Cardiff, UK
}

Since the 1990s the educational community has witnessed a proliferation of 'bullying' discourses, primarily within the field of educational developmental social psychology. Drawing on ethnographic and qualitative interview data of primary and secondary school girls and boys, this article argues that the discourse 'bullying' operates to simplify and individualise complex gendered/classed/sexualised/ racialised power relations embedded in children's school-based cultures. Using a feminist poststructural approach, this article critically traces the discursive production of how the signifiers 'bully' and 'victim' are implicated in the 'normative cruelties' of performing and policing 'intelligible' heteronormative masculinities and femininities. It shows how these everyday gender performances are frequently passed over by staff and pupils as 'natural'. The analysis also illustrates how bully discourses operate in complex racialised and classed ways that mark children out as either gender deviants, or as not adequately performing normative ideals of masculinity and femininity. In conclusion, it is argued that bully discourses offer few symbolic resources and/or practical tools for addressing and coping with everyday school-based gender violence, and some new research directions are suggested.

\section{Introduction: bullying as a normative discourse}

Heightened public awareness of bullying in schools over the last two decades has led to a surge of anti-bullying policy development, implementation and evaluation. To date, there are over $50 \mathrm{UK}$ non-governmental organisations dedicated to anti-bullying policy and advocacy work in schools (see http://www.anti-bullyingalliance.org.uk).

\footnotetext{
ॠCorresponding author: Department of Educational Foundations and Policy Studies, Institute of Education, University of London, 20 Bedford Way, London, WCIH OAL, UK. Email: j.ringrose @ioe.ac.uk
} 
Governmental resources are increasingly being devoted to standardising anti-bullying work in schools in line with the Every Child Matters (Department for Education and Skills, 2004) mandates. For example, the Department for Children, Schools and Families (DCSF) is providing $£^{3}$ million in the financial year 2008-09 for anti-bullying programmes to implement their most recent overarching set of guidance under the title, 'Safe to learn: embedding anti-bullying work in schools'. The last decade has thus witnessed an intensification of bully discourses, which, as we will show, are frequently framed around a binary logic of protection (i.e. 'victims' of bullying) and vilification (i.e. pathologising 'the bully'). Moreover, the discourse of bullying has become a highly visible, regulative socio-cultural phenomenon circulating well beyond the institutional cultures of schooling, or wider discourses of 'toxic childhoods' (Palmer, 2006), as well as adult social and moral degeneracy, with all the makings of a contemporary 'moral panic' (Blackman \& Walkerdine, 2001).

For example, in 2007, the bully discourse permeated the arena of popular culture, in a UK media frenzy over Jade Goody, Jo O'Meara and Danielle Lloyd's 'bullying' of Bollywood star Shilpa Shetty on UK Channel 4 television's Celebrity Big Brother. Now magazine's cover on January 29, 2007 declared, 'Jade we hate you: the nation turns on thick, racist bully'. In this case, the signifier 'bully' carried a host of 'condensed' (Erassi in Hey, 2005) meanings that imbued it with classed, raced and sexualised truth claims. The reported mass desire and delight in consuming the sensationalised drama of Jade Goody's representation as racist bully and the public captivation with Shilpa Shetty as feminine victim shows how the hegemonic bully/ victim binary operates to simplify and individualise complex social and cultural phenomena. The ways in which Jade was systematically positioned as ignorant and aggressively racist further de-feminised her previous working-class, 'white trash', 'laddette' (Skeggs, 2005; Jackson, 2006) status ${ }^{1}$ and powerfully illustrates how 'bully' operates as a site of intersectional otherisation.

Our interest in briefly highlighting one of many cultural episodes is to provide a high-profile example of how the categories of bully and victim circulate in the public domain of UK popular culture and the media, and how they hold implicitly gendered meanings and effects. We want to underscore the seductive, yet regulatory grip of the bullying/victimisation discourses in society at large in order to think more fully about the meanings of invoking these categories through the formal and informal institutional culture of schools.

Central questions for this article, then, include: What does it mean to be called a bully or victim at school given the wider public meanings of such categories? How do the effects of being called a bully or victim differ for boys and girls in ways that are related to performing the normative ideals of masculinity and femininity, which are themselves raced, classed and encultured? What does it mean when the concept of 'bullying', which largely ignores socio-cultural dimensions of power and identity, constitutes the dominant discursive framework through which schools can interpret and intervene in everyday gendered and sexualised school-based conflict?

To begin to address these questions, we provide a brief overview of the ways in which research located primarily within the field of developmental social psychology 
defines and evaluates the phenomenon of school bullying. We critique the prominence of what is often an unproblematised concept of 'bullying' deployed in psychological and educational policy and research (see also Walton, 2005). We then outline our own feminist, post-structural theoretical approach and theories of performing gender (Butler, 1990). Here we draw upon our respective qualitative ethnographic and interview based research in primary and secondary schools to map the production of normative masculinity and femininity in children and young people's school-based cultures. We suggest how a range of 'normative cruelties'2 inhere in the social and cultural processes of becoming a recognisable gendered subject. What we mean by our concept of 'normative cruelties' is the ways performing normative gender subject positions invoke exclusionary and injurious practices (for instance, being a tough, physically violent boy, or a mean girl) that are taken for granted. We explore how such normative practices are obscured in the conceptual frameworks and discourses around bullying drawn on to make sense of this behaviour-what we call 'bully discourses'. Rather, what is identified as bullying (particularly in our site of inquiry, schools) tends to be that which transgresses normative gendered behaviour as this 'intersects' with other identity markers like class and race. An increasing body of educational research takes 'intersectionalities' or the cross-cutting of diverse axes of identity and resultant complexities of identity and experience seriously (Archer \& Yamashita 2003; Brah \& Phoenix, 2004; Phoenix \& Pattynama, 2006; Archer et al., 2007; Mirza, 2009). We adopt an explicitly post-structural variant of intersectional thinking, exploring intersecting discourses of race, sexuality, culture, religion and class and their performative effects (see Youdell, 2006; Ringrose, 2007a, b).

In addition, we trace how being labelled as bullies and/or victims at school can position boys and girls in various ways as 'gender deviants'. What we mean by the notion of gender deviant is that young people transgress expected and normative ideals of femininity and masculinity. Moreover, in responses to bullying events, normative gendered behaviour is often demanded of children (i.e. boys should 'stand up' for themselves and girls should 'be friends'). We suggest that the dominant 'bully discourses' employed to make sense of and address conflict offer few resources or practical tools for addressing and coping with everyday, normative aggression and violence in schools. Indeed, in neo-liberal contexts of competitive schooling starkly organised around clear winners and losers (Lucey \& Reay, 2002), bully discourses operate as yet another site of abjection, 'demonisation' and social failure that children must navigate.

\section{Research on school bullying}

\section{Bully/victim binary}

Recent reviews of research on bullying in schools indicate that it has been overwhelmingly undertaken by psychologists interested in bullying as a developmental psychological problem among children (Smith \& Brain, 2000; Ma et al., 2001). The dominant meaning of bullying which has emerged amongst most researchers stems from the work of Dan Olweus $(1991,1993,1999)$, a prominent researcher on bullying 
in schools in the late 1980s and 1990s, who defines bullying as 'a subset of aggressive behavior characterised by repetition and an imbalance of power ... a student is being bullied or victimised when he/she is exposed repeatedly and over time to negative action on the part of one or more other students with the intention to hurt' (Olweus, 1999, p. 10).

Power, in these types of definitions of bullying, is conceived as an individual psychological and intentional acting out of aggression from bully to the victim, setting up a bully/victim binary. This binary also takes on an intergenerational, developmental dimension and thus an oppositional child/adult dichotomy, with bullying being conceived as a developmental stage afflicted 'young people' must grow out of. Reasons for bullying are also often attributed to the psychological characteristics of either the bully or the victim and there is a search for personality and family causes so that bullies and victims are both individualised and pathologised vis-à-vis what are constituted as 'neutral' or unafflicted children (Wolke et al., 2001; Connolly \& O'Moore, 2003). Sociological research has critiqued this developmental model of bullying for its focus on psychological typologies of bullies and victims, and failure to address the situational and socio-cultural dimensions of power along the lines of gender, class, race and sexuality (Lloyd \& Stead, 2001).

\section{Gender blindness vs. essentialised gender difference}

It follows from the lack of attention to the socio-cultural context that most research on school bullying has been 'gender blind' (Osler \& Vincent, 2003; Besag, 2006), focusing implicitly on boys as both perpetrators and victims of bullying (Olweus, 1993, 1999; Rigby, 1998). This traditional focus stemmed from definitions of bullying as mostly physical, with research studying male cultures of peer abuse (Duncan, 1999). When 'sexual bullying' has been the focus of investigation it is in the form of dangerous sexualities and usually extremes of violence or harassment, which neglects the centrality of (hetero)sexuality in children and young people's everyday cultures and relationships-both verbal and physical practices that are taken for granted (Duncan, 1999; Renold, 2002). Some educational researchers now researching gender differences in bullying draw on a psychological literature of gender-differentiated aggression to suggest that boys are aggressive in physical, direct ways, while girls are aggressive in 'indirect' and 'relational' ways (Owens et al., 2000a, b; Shute et al., 2002; Woods \& Wolke, 2003). We are highly critical of this developmental psychological literature on bullying, which tends to reduce and essentialise the relationship between gender, victimisation and bullying, as can be interpreted in the following quote about girls and boys as 'victims' and 'bullies': 'Helplessness and nonchalance were found to be typical responses of the girl victims, while boy victims tended to react to bullying with counteraggression' (Salmivalli et al., 1996).

Yet, what are the meanings that must circulate to argue that 'typical' girls are helpless or nonchalant, or that typical boys tend to show 'counteraggression'? The statement itself represents a speech act that constitutes gender norms (Butler, 1990). 
Thus, our critique of these developmental discourses is twofold: first, they obscure social power and hierarchies, including gender positionings and relations, and second, when they do address gender they reinvoke and/or legitimate existing gender stereotypes or essentialised norms of masculine and feminine difference, as evidenced in the above quote. This legitimisation of existing normative gender roles and hierarchies is actually a social/discursive 'effect' (Foucault, 1982) that the bully discourses have when they are used to describe, interpret and intervene in what is happening in the social worlds of children and young people, which we are interested in interrogating further.

\section{Feminist post-structural analysis: bullying as normative gendered 'performance'?}

In this article we use post-structural, feminist/gender theories of discourse and discursive positioning (Davies, 1989; Walkerdine, 1991) to argue that bully discourses and the signifiers 'bully' and 'victim' position young people in specific ways. We draw particularly on Judith Butler's (1990) theories of 'intelligible' gendered subjectivities, which suggest that gender identities are constituted through relations of social and cultural coherence between sex, gender, sexuality and desire, of which a pivotal practice is the Otherisation of those performances which rupture gender coherence. Butler's gender theories of gender performativity illustrate how 'classificatory systems, categories, and names that are used to designate, differentiate and sort people [like gender categories] ... work performatively to create the people they name ... [but] demand "repetition"" to sustain their normative force and give off the illusion of a 'proper', 'natural' or 'fixed' gender (Youdell, forthcoming). Normative gender performances are so insistent and repetitive (both conscious and unconscious) that they are, however, legitimised and taken for granted. So the 'normal' ways of 'performing' and enlivening or 'doing' 'girl' and 'boy' in the daily social and cultural rituals of bodily life, including gendered norms of aggression (e.g. boys are violent, girls are indirectly aggressive) are passed over in the classroom and schoolyard, as natural practice (Renold, 2005). What this means vis-à-vis bullying, is that often the 'normative cruelties' of doing gender through the practices of differentiation and Otherisation are legitimised, while our research shows that what is identified as 'bullying' tends to be that which transgresses normative performances of young masculinity and femininity.

As we proceed, we will use our feminist post-structural approach to analyse the performative effects of the bullying discourse, and how this contributes to discursive constructions of normative gender identity. We explore what behaviours are understood as normal, and therefore passed over, and which are marked out as bullying and lead to children and young people being discursively positioned as bullies and victims. In this process, we consider the demands to recoup appropriate masculinities and femininities evident in children's, schooling and parental responses to conflicts. We also explore the emotional effects of being labelled or marked out as a bully and as a victim, which include anxiety, anger and defensiveness. 


\section{A note on methodology}

The article draws on our respective research with boys and girls in primary and secondary schools. Emma Renold's data are from a year-long ethnographic study exploring broad patterns of gender and sexual relationship cultures with 59 10- and 11-year-old boys and girls in two semi-rural primary schools in the east of England: Tipton Primary (white, working-class and middle-class catchment area) and Hirstwood Primary (white, predominantly middle-class catchment area). All of the data presented in this article are from the children attending Hirstwood Primary. Alongside ongoing participant observation, one of the main methods employed to 'get close' to children's social worlds was through unstructured, informal exploratory 'group interviews' or what might be better termed as 'ethnographic conversations'. These conversations often took off in some quite unexpected directions, including discussions and disclosures on recognisably sensitive areas such as bullying, homophobia, sexual harassment, boyfriends and girlfriends, as well as emotive talk about schoolwork, play, friendships, music, popular culture, fashion and appearance.

Jessica Ringrose's research is from a pilot study which focused specifically on teen girls' (aged 12-14) experiences of aggression and bullying. The girls attended Herbert Secondary School, an ethnically diverse, inner-city school in an economically marginalised part of a large city in South Wales. The research employed focus groups and individual interviews to study girls' friendship groups. All the data in this article are from two successive focus group interviews and then in-depth individual follow-up interviews with five participants: Faiza (14) and Safa (12), who were sisters, and are both Iraqi-Welsh (Iraqi immigrants living in Wales for eight years); Lucy (13), Vietnamese-Welsh (born in Wales with Vietnamese heritage); Elizabeth (13), White-Welsh (born in Wales); and Gwyneth (13), White-British (born in England, living in Wales). Faiza, Lucy, Elizabeth and Gwyneth were all in year 9, and Safa was in year $8 .^{3}$

While aware of methodological limitations in bringing together data from diverse studies in different geographical and socio-cultural contexts, employing different methodologies, and working across age groups, our intention is to augment the rich data on normative violent masculinity derived from Emma Renold's research on friendship and relationship cultures among pre-teens with research findings from Jessica Ringrose's research, which focused explicitly on bullying among teen girls. In Renold's research there was little opportunity to discuss school anti-bullying interventions with girls, since girls' altercations typically went unnoticed by the school, something confirmed by other UK research, which illustrates that girls' often 'internalised' and less disruptive behaviour is constituted as 'not a problem' (Osler \& Vincent, 2003), leading to widespread neglect of girls' experiences of aggression and conflict. Ringrose's research, however, explicitly addresses this gap (see also Besag, 2006) and adopts in-depth interviewing methodologies to draw out painful and difficult-to-access stories from girls about bullying, and particularly their feelings about being constituted as a bully at school, which are more difficult to access via other methodologies (for instance, observation or a single interview). 
In sharing and re-interpreting the findings from these two studies we are not trying to 'generalise" 4 to all children and young people, something that would prove particularly difficult given the distinct cultural locales of the studies and the small pilot size of the Welsh study focused on girls and bullying, in particular. We are also cognisant of the partiality of the data as only 'indicative' of gender norms and deviations in relation to bullying. However, bringing the powerful data surrounding masculinity and bullying from Renold's research into dialogue with the insights into femininity and bullying from Ringrose's research has been a productive analytical exercise enabling us to find continuities and differences across the studies, thereby illuminating a greater range of experiences of negotiating bully discourses as a highly gendered phenomenon. ${ }^{5}$

From here, the article is divided into two sections: the first focuses on intelligible pre-teen masculinities and the role of normative masculinity in constituting the 'boy bully' (as gendered 'other') and in strategies to rescue the 'boy victim'; the second focuses on intelligible teen femininities and the role of normative femininity in both the constitution of the 'girl bully' (as gender 'other') and in strategies of intervention and prevention. Gender intelligibility is, in each episode, carefully contextualised in its social and cultural context (e.g. white, middle class for Renold's research and white, and minority ethnic, working class for Ringrose's research).

\section{'Intelligible' masculinities}

Research on masculinities in the UK, USA, Canada, Finland and Sweden has illustrated how gender-based and sexualised forms of aggression, harassment and violence are central in the production of dominant heterosexual masculinities across primary and secondary schooling (e.g. Mac an Ghaill, 1994; Connell, 1996; Kehily \& Nayak, 1996; Kenway \& Fitzclarence 1997; Connolly 1998; Mills, 2001; Skelton, 2001; Renold, 2002; Frosh et al., 2002; Sunnari et al., 2002; Pascoe, 2007). Investing in and publicly projecting 'tough' and/or physically violent embodied performances often represents a normative way of 'doing boy'. Renold's data illustrate, in sustained and repeated ways, the routinisation of violence and aggression in boys' school-based cultures. The school playground constitutes a 'battlefield' where boys become 'little warriors' through fighting and other forms of physical violence (Jordan, 1995). Recreating games with physical violence as the dominant narrative (e.g. the 'tripping up game'), mythologising and thus reliving past fights (e.g. 'did you see that fight') and performative rituals (such as showing marks or scars [Best, 1983]) were all ways in which 'tough' masculinities were produced and maintained (see also Francis, 1998; Connolly, 1998; Skelton, 2001). The following extract illustrates the normal, everyday understandings of physical violence as 'play':

(Rick confronts Ryan on how he used to 'beat' him up in Year 5, age 9-10)

Rick: You used to beat me up

Ryan: No I didn't/

Rick: Yes you did, you did body slams on me 
Ryan: That was because we were playing fights

Rick: Were we?

Ryan:Yeah

Indeed, the gaming of violence, a normalised discourse in most playground cultures, prevented many boys, like Rick, who experienced such 'play' as problematic, from combating the oppressive everyday effects of physical violence in playground culture. Rather, developmental, social and cultural norms were invoked in ways that legitimised such 'beat me up' discourses as 'just playing' or as socially acceptable forms of selfdefence. The following extract illustrates the ways in which surveillance by playground supervisors is circumvented and continuance of the 'tripping up' game secured:

Ryan: It's quite fun if you don't get hurt

ER: So who/

Ryan:It's not like really mad violence, you just trip em up/

Sean: Like Ryan you were going after James because and then me and Chris like jumped up and pushed and smacked him right/

Jake: Yeah yeah and we were standing there and Sean and Sam comes in and goes 'stop fighting' and kicked him right at the same time and they go, 'aaaagah' (they all laugh)

ER: How do you get away with all this fighting in the playground, don't the dinner ladies stop you?

Sean: Yeah, but if they do, if they see you and if they're like looking and someone says stop it, you like walk to another place, like you walk over to the other side and start again.

This extract also highlights how systemic physical violence is normalised through the blurring of boundaries between games, play-fighting and violence, with dominant masculinities tolerated and legitimised (often through humour; see Kehily \& Nayak, 1996). As becomes more apparent below, rarely did such oppressive behaviour come to the attention of staff. If it did, it was unlikely to be interpreted as 'bullying' and thus unlikely to justify intervention. The question that remains, then, is which violences do 'count' as violence and warrant intervention?

\section{Heroic masculinities and gender deviants: constituting the boy bully}

Diane Reay's (2002) research into the gendered cultures of primary school boys and girls powerfully illustrates how the violences that emerge from boy bodies are not merely sanctioned; rather, they are demanded and usually couched within a discourse of heroic masculinity, where fighting is rationalised through masculine discourses of protecting the self or victims of violence. This dynamic was evident in Ringrose's data where girls used discourses of heroic masculinity to call upon other boys to normatively discipline boys who violated appropriate modes of heterosexualised appearance and/or behaviour:

Lucy: William Brown, he's got long hair, like girl long hair, about that long, all blond.

Gwyneth walked past him and as a joke she just like/ 
Gwyneth: I just like went like that to his hair like/ (makes flicking motion).

Lucy: Because you touched his luxury flowing locks! (Laughing)

Faiza: He ... got up, grabbed her, my, her neck and smacked her against the wall and then she couldn't breath, that's how boys react. And then, and then I was there, I saw everything and I told a couple of boys in my year who are like the hard boys.

Lucy: So I told this boy called Patrick Dunsmuir and they had the guts to go up to William Brown and teach him a lesson.

JR: What did they do?

Faiza Physically or mentally (laughing)?

Lucy: They pulled him!

Girls: (all laughing).

JR: So you told them what they had done to Gwyneth and they retaliated ...

Lucy: Yeah because they thought it was wrong like what he done.

Elizabeth: Because he hits girls!

In this excerpt a boy that enacts public violence against girls, thereby violating the norm of heroic masculinity, is punished. Indeed, boys' violence appears to be much more readily sanctioned when it dramatically and publicly transgresses class, sexual and gender codes, as is also evident from Renold's research below:

(initial question was prompted by Sam's comment that Stu 'beats girls up')

ER: So Stu, you don't hit the girls at all?

Stu: No.

ER: So are they just making / it all up?

Sam: I do.

ER: I know you do.

Sam: Coz they're always going like this (hair ruffling)

ER: So you hit them back?

Sam: Yeah.

ER: They were telling me that sometimes you thump them in the chest (I obtained the girls' consent to confront the boys)

Sam: Yeah, yeah he does (laughing).

Stu: No.

James: He's, he's a women beater he is.

Sam: Man slaughter.

Jake: He's like someone out of Cracker ${ }^{6}$

James: Stu can't beat up boys so he beats up girls.

When the girls challenge Stu's 'masculinity' through hair ruffling, his 'friends' position both the challenge and Stu's retaliation (thumping the girls in the breast area) as 
marking him out as ambiguously masculine in ways that resonate strongly with the example from Ringrose's data above. Here, Stu's violence against a girl becomes a signifier of a classed, pathological version of 'wife beating' masculinity. This is a masculinity strongly differentiated from normalised forms of masculinised gaming violence that we elaborated earlier.

Boys consistently differentiated boys' enacting 'mad violence' against other boys, if a boy went 'over the top' thereby exceeding acceptable performances of physical violence, from 'playing'. Degrees of excess thus seem to be required to mark out a subject as deviant and pathological ('mad'). Consequently, it appeared that only if a boy enacted 'unmerited' violence against other boys or girls, this was constituted as dysfunctional and overly aggressive in ways that were read through gender, sexuality, class and culture and led to being constituted as a bully at school.

Thus, to be explicitly positioned as a 'bully' either by the school or by other children was neither desirable nor powerful for boys, in fact, the very opposite. Once labelled as 'bully' it could function in contradictory ways, as a marker of weakness, pathology, sexual deviation and class-based irrationality, as was particularly evident in the positioning of Stu as a low-class wife beater above.

\section{'Stand up for yourself!': recouping normative masculinity}

The gender logics of playground masculinities dictate, however, that to be a male victim constitutes one of the most serious breaches of heroic masculinity. To be discursively positioned as victim is to mark out the male subject as sexual deviant, as feminised, and therefore as an abject subject. In using the notion of 'abject' (Ringrose \& Walkerdine, 2008) we again draw on the theoretical vocabulary of Butler (1990, p. 170), who describes abjection as 'an "expulsion" followed by a "repulsion" that founds and consolidates culturally hegemonic identities along sex/race/sexuality axes of differentiation ... the operation of repulsion can consolidate "identities" founded on the instituting of the "Other" or a set of Others through exclusion and domination'.

The position of male victim was abhorred by young people and adults alike, and to be rectified at all costs. Indeed, responses by staff to this positioning were consistent demands to stop complaining and toughen up:

Neil: I used to 'tell' [the teachers] in years 4 and 5 but they just used to say 'stop telling tales'

ER: Really?

Neil and Graham: Yeah

The 'super-vision' of boys' experiences of physical violence was hardly super; rather, it worked to normalise and sustain the culture of masculine violence:

ER: What about the dinner ladies? Can you tell them?

Neil: They're not bothered, they're not bothered 
Simon: Yeah because if someone kicks you or something, they/

Neil: You /need to be crying before they take any notice

Graham: They call you a wimp

Simon: You have to be either crying or lying on the floor with loads of people round you

... to get any attention

As Simon illustrates, only where there is a clearly demarcated victim and perpetrator with visible unambiguous signifiers of distress (e.g. 'you have to be either crying or lying on the floor') would official school sanctions be implemented. However, in peer, teacher and parental cultures, where there is extreme investment in competitive, violent masculinities, the boys are left with few options:

ER: Have you told, or can you tell your parents what goes on sometimes?

Graham: No

Neil: No, coz they'd go mad

ER: Can you tell them, would they come up to the school if they found out you'd been hit and teased

Graham: No probably not

Graham: My dad told me to stick up for myself, but he doesn't know them like I do (almost in tears)

ER: I know it's very difficult (he nods)

Simon: If I do tell my mum and dad, what happens, coz my dad, he teaches me some moves, he teaches me how to block, by putting two arms in front of me

ER: So they tell you either to stick up for yourself, or in your case, Simon show you how to do that, but they wouldn't /

Graham: If if if I do something to them, they just carry on, they do it again

Neil: My mum and dad just say just walk away

Graham: But you can't! (exasperatedly)

Neil: Yeah.

ER: But it's difficult, because they can still come after you

Graham: I know

Simon: ... and if I do get into a fight and I tell my mum and dad and say 'well I just thumped them and I just ran off, so and my dad says 'so you won the fight then' and I go 'yeah' (unconvincingly) and my mum and dad go 'good for you'

As Simon's father illustrates through his desires for his son to 'fight' and 'stand up for himself', boys are repeatedly called upon to perform hegemonic masculine (Connell, 1987), hard, 'tough guy' discourses. The bully discourses formalise and entrench a set of unviable subject positions for boys where both bully and victim are viewed as pathological, as signs of failed and deviant masculinity. The constitution of both boy 
bully and boy victim are thus sites of vehement 'abjection' and 'dis-identification' (Butler, 1990): the boy bully, a weak girl/wife beater or 'mad' man, among other distinctions, the boy victim, an untenable position rendered invisible for the most part by the school and parents. Practices of normalised masculine violence, which we may wish to challenge as oppressive, are defined outside the purview of the bully discourse. Thus anti-bullying discourses do not offer symbolic or practical resources that boys can call upon for help in negotiating violence and conflict. Rather, bully discourses support the institutionalised structures of masculinity and the normalised gendered power hierarchies and are therefore reproductive of normative social violences, instead of offering viable tools for mediating conflicts for either children or adults.

From girls invoking heroic masculinities, to dinner ladies' avoidance of physical violence, to parents' demands to 'toughen up', hegemonic heteronormative masculinity prevails. Indeed, in the wake of such impossible predicaments it is no surprise that by year 6, boys like Simon, Graham and Neil no longer sought 'help':

ER: What do you think you can do to stop Ryan and that bullying you ... is there anything that the school could do?

Neil: Well/ nothing really

These boys reverted to strategies of silence, not surprising in light of demands to 'stop telling tales', removing themselves from the physical spaces of their dominating peers or ditching their gender misfit friends by attempting to 'befriend the 'enemy' through helping dominant boys with academic work or trying valiantly to master football (see Renold, 2005). As we explore next, silence as a response to the lack of viable strategies in coping with everyday school-based conflict also resounds in the girls' narratives.

\section{Intelligible femininities}

Decades of feminist research within sociology, criminology, psychology and education have powerfully illustrated the cultural mandates of ideal/normal femininity as passive, nurturing and accommodating (Gilligan, 1982; Walkerdine, 1991; Campbell, 1993; Paechter 1998; Francis, 2005; Gonick, 2004; Aapola et al., 2005). Multiple studies on girlhood have illustrated the cultural expectations that to adequately perform the normative subject position of girl in the contexts of compulsory heterosexuality means to be 'nice' (i.e. good, caring, nurturing, sexually innocent/respectable; see Hey, 1997; Walkerdine, 1997; Driscoll, 2002; Kehily et al., 2002; Tolman, 2002; Renold, 2005; Ringrose, 2008a). Thus, where norms of masculinity call for the performance of toughness and sanction violence, femininity calls upon girls to perform niceness. Ringrose's data illustrate how the typical, normal or ideal girl not only has to be 'supportive' and 'there for you', but also non-competitive and 'friends with everybody':

Gwyneth: Not like stuck up or nothing. Not like always boasting about what she has bought and stuff like that. Funny. Kind. 
Elizabeth: They'd be pretty and they'd be blonde (Elizabeth is blonde). And they'd be like fun and playful and nice and ... hang around you all of the time like Gwyneth, except the blonde thing ...

Faiza: Sporty, pretty, funny, intelligent, friendly, kind and fits it ... gets along with everybody, not just in one group, she is like in everybody's group.

JR: Do you know any girls like that?

Faiza: No.

This list of idealised qualities to which girls are held hostage is not just their own private fantasy. These are the myths and desires underpinning a historically embedded western cultural imaginary of idealised femininity (Walkerdine, 1991; Ringrose \& Walkerdine, 2007). Moreover, as illustrated in Faiza's negative response to the interviewer's question, 'do you know any girls like that', these qualities are not only formidable, but unachievable (much like the hegemonic masculine discourses regulating boys' behaviours; see Renold, 2005, p. 67). These normative aspects of femininity contribute to the repressive dynamics much commented upon in the developmental psychological literature that classifies girls as 'indirectly' or 'covertly aggressive' (Crick \& Rose, 2000). Our goal is to question the 'naturalness' of the quality of indirect aggression, and to point to the gender norms and social expectations of niceness at all costs that underpin girls' responses of 'repressive', 'covertness' (Brown, 1998, 2003). Bitchiness and meanness are an expected counterpoint to feminine niceness (Hadley, 2003; Ringrose, 2006). As the following extract illustrates, a nice/mean binary within femininity is clearly evident:

Lucy: I think that girls can be really nice and then they can be really like horrible.

Faiza: All girls are two faced.

Lucy: Yeah, everyone is, do you get what I mean, like everyone slags someone off behind their/

Elizabeth: You know Louise and that, they all slag each other off behind their backs.

Lucy: I know, and then they're best friends. When they're with each other, they like, hi and then as soon as like Imogene goes ...

Elizabeth: None of them like Imogene, it's rude.

Faiza: Like everyone slags someone off in their lives, do you get what I mean?

Lucy: Yeah but what's that got to do with girls being strong and sticking up for themselves.

Gwyneth: Because girls are mean.

The girls describe repeatedly their contradictory convictions against the fictive lure of girls as nice, that girls are actually mean, two-faced, cannot keep secrets, and are systematically betrayed and talked about by one another. Meanness is therefore part of the normative cruelties of 'doing' girl.

A primary way girls are socially sanctioned to express meanness is through subtle and direct regulation of other girls' sexuality. As others' research indicates, it is normative for girls to position themselves and others in sexual hierarchies, invoking regulative discourses around sexuality, appearance and behaviour in the private spaces of their 
friendship groups as a mode of constructing idealised femininity (Kehily, 2002; Youdell, 2006). This is particularly evident in comments from both Renold's research with primary school girls and Ringrose's research with secondary school girls:

Carrie (age 10): I'm not being horrible but have you seen Trudy's skirt, it's her five year old sister's' and its like up here (draws an invisible line well above her knee) ... when she bends down you can see her bum ... some people say she's a tart

Faiza (age 14): At one stage Katie was dressing up in skirts the length of her knickers dressed like that, with like nothing there and she would be all really weird, in other words, she made herself small. It was like, $\mathrm{O}$ she walked past a boy and she goes, ' $\mathrm{O}$ he fancies me'.

Much like the masculinised gaming violence, however, these typical modes of heterosexualised regulation and intersubjectively negotiated power hierarchies among girls tend not to be categorised as bullying (Duncan, 2004; Bright, 2005; Currie et al., 2007). There is little questioning of, or intervention upon, these practices unless they transgress the private realms of girlhood 'gossip' to the public domain of the school ground or wider school community (Besag 2006). We suggest that the corresponding emotional position in relation to the demand to inhabit passivity (and the niceness and/ or indirectly mean norms of feminine behaviour) is victimhood. As we explore further below, understanding the self as victim of feminine indirect aggression, or legitimising one's performance of meanness seemed a normative feminine position to occupy.

\section{Heteronormative femininities and gender deviants: constituting the girl bully}

In this section, we explore how when girls violate the normative conditions of 'relational aggression' beyond secret/private rituals (for example, through physical violence or overt/public verbal confrontations), they risk being constituted as gender deviants. We also show that to be positioned as a bully is problematic for girls, because it breaches normative (classed and raced) femininity in its association with discursive masculinity. The following excerpts involve girls in a focus group discussion responding to their experiences of an anti-bullying intervention at their school over a conflict with a girl in their friendship group, Katie:

JR: So I just want to try and understand how it first happened that you got into this disagreement.

Elizabeth: [Katie] thought she was better than us ... like, 'oh who fancies you, no one, oh well I guess they all fancy me then'

Gwyneth: Like she would say really horrible stuff to me and Elizabeth like, make us feel all small ... She like made out that I was like a slut, only she was. And then she like was really horrible and told a secret of Elizabeth's to like boys ... and we were angry with her.

Gwyneth: It probably would have blown over, it probably would have been just a little fight and we wouldn't have talked for a few days and then make friends. But then her mum got involved and like rang up the school and said that we were bullying her.

Gwyneth and Elizabeth describe how Katie made them 'feel small', how they confronted Katie at school, and how Katie told her mum, who complained to the school. By discursively framing the incident as 'bullying', the school then calls a 
meeting with the girls (now 'bullies') and Katie (now 'victim'). The girls' open verbal fighting transgresses what are middle-class codes of appropriate feminine behaviour as hidden, silent, secretive, covert and thus repressive (Ringrose, 2006). Gwyneth describes a fight over being positioned as a slut. However, the complex meanings of the fight are never actually addressed in either the parent or school response, as we discuss below. Through the open challenge and parental complaint, Katie becomes constituted as the 'victim' and the others as the 'bullies'. Our concern is that the bully/ victim binary offers few material or practical resources for the girls to articulate or address the actual social content of meanings of their conflict. It also has a very problematic discursive effect of engendering heightened defensiveness, anger and anxiety, as we explore next.

\section{'Fust be friends!': recouping normative femininity}

The school's response in addressing the gendered and sexualised conflict demanded the recouping of 'good-girl', 'nice' femininity via a historically embedded childhood discourse, 'just be friends' (see also Ringrose, 2008a), as Gwyneth explains below:

Gwyneth: [In the meeting] Katie said, 'no they are not bullying me because I did something horrible' ... it's like, 'I can see why they'd be angry and mean and stuff like that'. But her mother said, 'no', like rang in and we all got in trouble and we got told that we were bullying her but they didn't even hardly listen to our side of the story. They just believed her mum and stuff. But then when we told them what happened they said, 'oh, OK you weren't bullying her and everything, but just like be friends'. But then ... she just left the school.

Gwyneth's narrative indicates how the bully discourse shifts back and forth, 'we were bullying her', 'OK you weren't bullying her'-illustrating its slippery nature, and ineffectualness. The solution proffered, 'just be friends', at once trivialises their problem and obscures the heterosexualised or 'heteronormative' (Youdell, 2006) competition and conflict (who do boys 'fancy', who's a 'slut') (Ringrose, 2008b) that organises the fight. It also re-regulates the girls strongly back into normative femininity (be friends!), deflecting responsibility for coping with conflict back onto the nurturing and passive victim motifs of idealised girlhood, in the incitement to get along no matter what the context or cost.

As we see with Gwyneth's narrative above, the girls also attempt to argue that Katie 'knew [she] did something horrible' so they can reposition themselves as victims, which is a more comfortable side of the binary to occupy for girls. Invoking the bully and victim discourse is a vicious cycle. The bully/victim binary fails to unpack any of the gender norms (bully as deviant girl, victim as more acceptable girl) inhering with the bully discourse itself. In the context of these findings, to be constituted as bully as a girl was a site of abjection and shame-with very difficult effects (i.e. often exacerbating conflict or anxiety). Defensiveness and anger simmered among the remaining friendship group, in the wake of being positioned as bullies. In group and individual interviews the girls responded variously by saying, 'I hate her' and calling her a 'two-faced pig', a 'slut', 'ugly', 'disgusting', 'annoying', 'irritating', 'acting horrible' 
and guilty of making herself and the others 'feel small'. Faiza in particular carried a great deal of defensiveness:

Faiza: I personally thought that we had sorted it. We all gave each other hugs, we walked home the same way and then suddenly she didn't come to school any more ... all of a sudden she'd want to change school ... and then on MSN she'd be so scared to say it to our faces, she'd go on MSN 'oh, you stupid cow, dur, dur, dur, dur, dur'. I didn't care about that. If she had guts, she would say it to my face. And every time she was around me she would be like, 'oh god, I'd never want to start a fight with you'.

Faiza: She said to us that her mum made her change school ... Make up your mind mum. She took her daughter off school for three months, so she can find her another school ... Her mum would [should?] have been arrested, put in jail for not letting her daughter to go to school.

JR: It seems like it was ... a difficult situation.

Faiza: She brought it onto herself. She talked about Gwyneth to me, she talked about me to Gwyneth, she talked about Lucy to Lizzy, she talked about Lizzy to Lucy, how stupid is that? If you are going to talk to someone about someone else, it would be someone ... we weren't best friends with. Then at last, she just left. And that had to be the happiest bit of Herbert for us four girls. She made us go through all that trouble of coming into a classroom and the teacher locking us in and we had to sort it out and then she left. Good.

Faiza recounts Katie calling her a 'stupid cow' within the virtual space of MSN, ${ }^{7}$ but as fearing Faiza in person. Faiza states: Katie would 'be so scared to say it to our faces', and would say 'oh god I'd never want to start a fight with you'. It is also significant that in parent interviews Katie's mother is recounted by another parent, Sue, as being fearful of the school and removing Katie from the school, in ways that are described as related to the increasing diversity and perceived behavioural problems at the school:

Sue: This fear that a lot of the parents that I knew had about their children going to Herbert [Secondary] ... There were all these different strategies people had got to stop that from happening. So, one thing you can do is go to a Welsh school ... I remember somebody explicitly saying to me you know that it was a good way of avoiding having to go to a school with so many black people in it ... probably eight or nine people had left in various ways ... it seemed to me that [was] some of what was going on with Katie.

While the specific issues of parents' racialised fears and 'school choice' informing Katie's mother's decision to remove her daughter from the school and transfer her into a higher performing comprehensive is discussed in much greater detail in another article (Ringrose, 2008a), our interest here is to highlight that Faiza is a racially marginalised, Muslim subject, which intersects in complex ways with being positioned as a threatening, masculinised, bully girl. Discourses of Islamophobia are highly visible in the UK press and popular culture (Khan, 2006). While a detailed analysis of race, religion and bullying is beyond the scope of the article, it is possible to suggest that Faiza's being positioned as a bully resonates in complex ways with the common, everyday, racialised, 'religioned' (Youdell, 2006) and masculinised associations of Muslim faith with violent aggression (in ways similar to Jade Goody being constituted as working- 
class bully through associations with working-class violent masculinity). The raced and 'religioned' aspects of Faiza's identity operate, therefore, in a 'constellation' (Youdell, 2006) with her gendered and sexualised identity and inform how she is positioned as masculinised and racialised bully and non-feminine object of fear.

While Faiza also works hard to 'dis-identify' (Gonick, 2004) with the bully label and to question why others are fearful of her, being positioned as bully in this way has lasting emotional effects of frustration and defensiveness. Above, Faiza suggests that Katie's mum should have been 'arrested, put in jail' (since according to this account she took Katie out of school for three months). We understand this to be a form of revenge fantasy ${ }^{8}$ and a defensive emotional response to her feelings that Katie's mum was responsible for the school's 'locking us in' a classroom, during the anti-bully intervention, and for taking the dramatic action to remove Katie from the school, and for the girls and Faiza in particular being publicly constituted as bullies.

What interests us in this account is that much like the boys in Renold's research, it seems bully discourses actually offered these particular girls, teachers and parents very few resources for positively coping with conflict or addressing the intersectional complexities of the events. Indeed, in the wake of such inadequate anti-bully interventions, girls, like the boys, developed fears of either telling adults about their problems or having their conflicts discovered by adults; reverting to silence and secrecy:

JR: Do you think you have learned anything from this or?

Gwyneth: Probably, it's probably best to like, not to say it in front of people because it might make them feel that people are ganging up on like the person you are talking to, just get them by themselves and say it. We did kind of do that, me and Elizabeth got her by herself and everyone thought we were going to like argue so they all crowded around kind of thing, like all our friends, like, 'oh what's going to happen'. But it kind of made it worse ... We learned to like talk to them quietly by themselves.

The need to keep incidents secret indicates, again, the shame and stress of negotiating the type of public spectacle incited through the school's bully discourses. The effect of the school bully discourses, we found, therefore, was a renewed desire for covertness as a tactic to avoid public humiliation, since to be positioned as a girl bully transgresses the normative conditions of femininity. It is not surprising, that such positionings have prolonged effects of anxiety, defence and denial, as can also be interpreted from Lucy's comments below:

Lucy: Some people would call that bullying. I wouldn't because maybe bullying, sometimes it can be like physical and we didn't do anything to her. Sometimes we'd just like say it but we didn't shout at her, we didn't gang up on her, we tried to talk it out calmly, like properly and then, but then that didn't work, so we just stopped. So some people would call it bullying but I wouldn't. Bullying, sometimes it can be someone's opinion, not like something that is true ... we didn't bully her.

In ways similar to Faiza, Lucy tries to strongly dis-identify with the category of bully. She works to distance herself from the pain and difficulty of this situation in a way that is indicative of the hopelessness of an impossible scenario and an anti-bullying intervention that simply, as she puts it, 'didn't work'. As with the boys in Renold's 
research, in the face of such difficulty, 'stopping' attempts at resolution seem sensible, and silence and denial resound.

\section{Conclusions}

In a recent British Educational Research fournal article exploring the ways in which secondary school staff understood and responded to school-based student violence, schools were either silent or experienced frustration in their struggle to address issues around gender, sexuality or race 'in a policy environment which was itself often silent over them' (Watkins et al., 2007, p. 73). Despite a marked shift in the most recent anti-bullying policy recommendations (DCSF, 2007a, p. 2), which now include different forms of what they term, 'prejudice-driven' bullying (i.e. 'sexist', 'sexual', 'racist', 'faith-based' or 'homophobic') alongside 'types' of bullying (e.g. name-calling, hitting, rumour-spreading, cyber-bullying, etc.), guidance around issues of gender, sexuality and culture end there. 'Sexual' bullying is reduced to 'homophobic bullying' and gender is only referred to, like in many other education documents (e.g. DCSF, 2007b), as either a fixed variable of biological sex difference (male-female) or through essentialistic discourses acknowledging that boys and girls bully in different ways. The policy silences and institutional failure to tackle gendered and sexualised violences in schools endure (Leach \& Mitchell, 2006) and the need to engage with how anti-bullying policy operates at the level of school practice and discourse continues. In the context of the new Gender Equality Duty, we wonder to what extent this framework will mediate future debates and policy frameworks. Now that it is incumbent upon policy makers and schools to develop their understandings of how issues of gendered and sexual conflict and violence continue to underpin school cultures (Burman et al., 2007; Renold \& Murphy, 2007), further research mapping the discursive effects of the Gender Equality Duty is needed.

Responding to the silence around the gendered, heterosexualised dynamics of violence for children and young people, this article has foregrounded how 'bully discourses' are organised around binaries of bully and victim, which enact rigid gender norms and support heteronormative power relations. Bully discourses dramatically permeate the social at the level of popular culture, constructing binaries that pathologise the bully often in gendered, but also racialised and class-specific ways, as we indicated in our brief introductory analysis of Jade Goody and Shilpa Shetty. But the central concern of our article has been to demonstrate how what are largely developmental psycho-educational discourses of bullying are now so accepted (formally and informally) in schools that they have gained hegemonic status. To problematise this we have pointed to some of the effects of bully discourses brought to bear on young people's conflicts in school, which pathologise children, largely ignore and/or render violent altercations normal, and leave children with few ways to cope with residual anxiety, defensiveness, guilt and feelings of failure. In the context of a neo-liberal, competitive, classed, raced and heterosexualised educational economy organised around individualised success and failure (Lucey \& Reay, 2002), bullying discourses place responsibility for social and behavioural 'failings' squarely 
back onto the shoulders of those who transgress the normative expectations for doing 'boy' or 'girl'.

We want to challenge these effects of power, and have attempted in this article to map out and deconstruct the bully discourses in operation through a feminist, poststructural theory of power, which outlines how norms and symbolic structures construct 'intelligible genders' and how such symbolic structures of gender are performative (Butler, 1990; Youdell, 2006). This approach has helped us to map what we have called the 'normative cruelties' inhering in heteronormative masculinity and femininity - practices often sanctioned and required in schooling cultures, but which are glossed over by the anti-bullying framework. Indeed, what gets called bullying is often that which violates heteronormative gender identities, such as the wife/ girl-beater boy or the confrontational, 'non-feminine' girl. Our tracing of the effects of the bully discourses often led to demands for an explicit recouping of gendered norms of behaviour; for boys to be heroically and 'playfully' violent and for girls to be repressively and secretly 'mean'.

The application of Butler's theories (see David et al., 2006) has enabled an analysis of how girls and boys are incited to 'perform' conflict and violence in particular ways through affective norms of masculinity and femininity, which are also 'intersected' by culture, class, race/ethnicity and other axes of identity and power. More than a tool of critique, therefore, the feminist post-structural approach has afforded us a more complex and contradictory mapping of negotiations of conflict and violence amongst young people in ways that expose the subject positions of bully and victim as simplistic and reductionist. We have begun to show how children employ more complex discourses such as 'fighting' or being 'angry', 'sticking up for yourself', 'having a go', 'breaking friends', among others, all of which call into play dynamics and relations of everyday conflict and violence that are not accounted for when pushed into a binary symbolic structure of victim/bully. Importantly, our analysis is not to be conflated with an advocation of a 'no blame' approach (Maines \& Robinson, 1992), which flattens out power relations. Rather, what the feminist post-structural approach allows for is a more nuanced mapping of relationality and the complex, mulitplicitous 'effects' (Foucault, 1982) of gender and sexual power inequalities in the social terrain of schooling. Further research illuminating the social complexities of conflict among children, developing intersectional approaches to understanding and challenging regulative gender and (hetero)sexual discourses, as these are cross-cut by race, class, cultural and other specificities, would be a welcome addition in addressing the weaknesses in policy, practices and thinking around children's and young people's experiences, when most conflict is interpreted and addressed via the conceptually limited framework of 'bullying'. 9

Thus, in conclusion, we suggest the hegemony and ultimate stranglehold of the bully and anti-bully discourses over educational research, policy and practice is in much need of a critical overhaul. We need to consider theoretical frameworks and methodologies that can examine the differential effects of discourses around gender, bullying and violence for girls and boys in schools and thus the social, cultural and subjective dimensions of how such discourses constitute, regulate, discipline and pathologise particular 
sets of institutional behaviours (Kehily, 2004). Such research, however, must be located within what we see as the intense social and academic competition of schooling environments (Bradford \& Hey, 2007) and account for how socio-economic processes, and diversities (in terms of intersecting class, race, cultural aspects) inform girls' and boys' gendered relations and conflicts within and beyond the school gates.

\section{Notes}

1. An interesting shift accompanies this story at the time of rewriting this article, since public interest in Jade has been massively reinvigorated through a new documentary, fade (Living TV, 2008/2009), documenting her struggle to survive cancer as a single mother. Jade's recent occupation of the more familiar female category of victim works (in part) to redeem her past transgressions, to become more appropriately, comfortably feminine and maternal (her relationship with her two young boys and her public marriage to Jack Tweed being the focal point of many of the media reports). Jade's subsequent death solidified a discursive shift from being constituted as 'sinner' to 'saint' and 'princess' as one UK Bishop described her. Jade's funeral certainly resembled Princess Diana's with 'thousands' assembling to watch the procession through London. As 'cancer victim' Jade is now defined as 'courageous' and 'an inspiration', as going from 'public ridicule and public rebukes to public respect' and rising up out of a 'disastrous start in life' (Telegraph, 2009).

2. We would like to thank Valerie Hey for insightfully introducing this notion to us in her comments on an earlier version of the article.

3. All participants' names throughout the article have been anonymised.

4. The principle of generalisation is not generally applicable to post-structural research, which operates according to principles of discursive locatedness and partiality of any research findings (O’Neil \& Morgan, 2001; Blaise, 2005).

5. It is characteristic to hide the research process, from data collection to analysis (Cresswell, 1994). However, comparing our research studies in depth has been an important methodological and interpretive process we would encourage others to 'experiment' with as they construct their research 'findings'. As Appel (1999) notes in his exposition on post-structural and psychoanalytically informed research, "research methodologies" are stories told after the fact to try to make rational a substantially irrational process'. By revisiting our research findings together we were able to make new interpretive discoveries and yield greater insights from each data set.

6. Cracker is the title of a mid-1990s UK television crime drama series.

7. For a more sustained exploration of friendship and conflict in the context of digital mediums like instant messaging and social networking sites, see Ringrose, forthcoming.

8. For a fuller discussion of Faiza as enacting revenge fantasies, see Ringrose and Renold (2008).

9. See Walton (2005) for important conceptual deconstructions of bullying frameworks.

\section{References}

Aapola, S., Gonick, M. \& Harris, A. (2005) Young femininity: girlhood, power and social change (London, Palgrave).

Appel, S. (1999) Psychoanalysis and pedagogy (Westport, CT, Bergin \& Garvey).

Archer, L. \& Yamashita, H. (2003) Theorising inner city masculinities: 'race', class and gender, Gender and Education, 15(2), 115-132.

Archer L., Halsall A. \& Hollingworth S. (2007) Inner city femininities and education: 'race', class, gender and schooling in young women's lives, Gender and Education, 15(2), 115-132.

Besag, V. E. (2006) Bullying among girls: friends or foes? School Psychology International, 27, 535-551. 
Best, R. (1983) We've all got scars: what girls and boys learn in elementary school (Bloomington, IN, Indiana University Press).

Blackman, L. \& Walkerdine, V. (2001) Mass hysteria, critical psychology and media studies (London, Palgrave).

Blaise, M. (2005) A feminist poststructuralist study of children 'doing' gender in an urban kindergarten classroom, Early Childhood Research Quarterly, 20(1), 85-108.

Bradford, S. \& Hey, V. (2007) Successful subjectivities? The successification of class, ethnic and gender positions, Fournal of Education Policy, 22(6), 595-614.

Brah, A. \& Phoenix, A. (2004) Ain't I a woman? Revisiting intersectionality, fournal of International Women's Studies, 5(3), 75-86.

Bright, R. (2005) It's just a Grade 8 girl thing: aggression in teenage girls, Gender and Education, 17(1), 93-101.

Brown, L. M. (1998) Raising their voices: the politics of girls' anger (Cambridge, MA, Harvard University Press).

Brown, L. M. (2003) Girlfighting: betrayal and rejection among girls (New York, New York University Press).

Burman, M., Batchelor, S. \& Brown, J. (2007) Challenging violence: girls, gender and violent encounters (London, Palgrave).

Butler, J. (1990) Gender trouble: feminism and the subversion of identity (New York, Routledge).

Campbell, A. (1993) Men, women and aggression (London, Harper Collins).

Connell, R. W. (1987) Gender and power (Cambridge, Polity).

Connell, R. W. (1996) Teaching the boys: new research on masculinity, and gender strategies for schools, Teachers College Record, 98(2), 296-235.

Connolly, I. \& O'Moore, M. (2003) Personality and family relations of children who bully, Personality and Individual Differences, 35(3), 559-567.

Connolly, P. (1998) Racisms, gendered identities and young children (London, Routledge).

Cresswell, J. W. (1994) Research design: qualitative and quantitative approaches (Thousand Oaks, CA, Sage).

Crick N. \& Rose, A. (2000) Toward a gender-balanced approach to the study of social-emotional development-a look at relational aggression, in: P. Miller \& E. K. Scholnick (Eds), Toward a feminist developmental psychology (New York, Routledge).

Currie, D. H., Kelly, D. M. \& Pomerantz, S. (2007) 'The power to squash people': understanding girls' relational aggression, British fournal of Sociology of Education, 28(1), 23-37.

David, M., Coffey, A., Connolly, P., Nayak, A. \& Reay, D. (2006) Troubling identities: reflections on Judith Butler's philosophy for the sociology of education, British fournal of Sociology of Education, 27(4), 421-424.

Davies, B. (1989) Frogs and snails and feminist tales (Sydney, Allen \& Unwin).

Department for Children, Schools and Families (DCSF) (2007a) Staying safe. A Consultation Document (London, HMSO).

Department for Children, Schools and Families (DCSF) (2007b) Gender and achievement: the evidence from pupils in England (London, HMSO).

Department for Education and Skills (2004) Every child matters: change for children (London, HMSO).

Driscoll, C. (2002) Girls: feminine adolescence in popular culture and cultural theory (New York, Columbia University Press).

Duncan, N. (1999) Sexual bullying: gender conflict and pupil culture in secondary schools (London, Routledge).

Duncan, N. (2004) It's important to be nice, but it's nicer to be important: girls, popularity and sexual competition, Sex Education, 4(2), 137-152.

Foucault, M. (1982) The subject of power, in: H. Dreyfus \& P. Rabinow (Eds) Michel Foucault: beyond structuralism and hermeneutics (Brighton, Harvester).

Francis, B. (1998) Power plays (Stoke on Trent, Trentham Books). 
Francis, B. (2005) Not/knowing their place: gendered classroom behaviour, in: G. Lloyd (Ed.) 'Problem' girls: understanding and supporting troubled and troublesome girls (London, Routledge).

Frosh, S., Phoenix, A. \& Pattman, R. (2002) Young masculinities: understanding boys in contemporary society (Basingstoke, Palgrave).

Gilligan, C. (1982) In a different voice: psychological theory and women's development (Cambridge, MA, Harvard University Press).

Gonick, M. (2004) Between femininities: ambivalence, identity and the education of girls (New York, SUNY Press).

Hadley, M. (2003) Relational, indirect, adaptive or just mean-recent work on aggression in adolescent girls-Part I, Studies in Gender and Sexuality, 4(4), 367-394.

Hey, A. (2005) The contrasting social logics of sociality and survival: cultures of classed belonging in late modernity, Sociology, 39(5), 855-872.

Hey, V. (1997) The company she keeps: an ethnography of girls' friendships (Buckingham, Open University Press).

Jackson, C. (2006) Lads and ladettes in school: genders and a fear of failure (Buckingham, Open University Press).

Jordan, E. (1995) Fighting boys and fantasy play: the construction of masculinity in the early years of school, Gender and Education, 7(1), 69-86.

Kehily, M. J. (2004) Gender and sexuality: continuities and change for girls in school, in: A. Harris (Ed.) All about the girl: culture power and identity (London, Routledge).

Kehily, M. J., Mac an Ghaill, M., Epstein, D. \& Redman, P. (2002) Private girls and public worlds: producing femininities in the primary school, Discourse, 23(2), 167-177.

Kehily, M. J. \& Nayak, A. (1996) Playing it straight: masculinities, homophobias and schooling, fournal of Gender Studies, 5(2), 211-229.

Kenway, J. \& Fitzclarence, L. (1997) Masculinity, violence and schooling: challenging poisonous pedagogies, Gender and Education, 9(1), 117-133.

Khan, H. (2006, February 12) The bad news: British Muslims have been let down, and extremism is the result, The Independent.

Leach, F. \& Mitchell, C. (Eds) (2006) Combating gender violence in and around schools (Stoke-onTrent, Trentham Books).

Lloyd, G. \& Stead, J. (2001) The boys and girls not calling me names and the teachers to believe me: name calling and the experiences of Travellers in school, Children and Society, 15(5), 361-374.

Lucey, H. \& Reay, D. (2002) Carrying the beacon of excellence: pupil performance, gender and social class, Fournal of Education Policy, 17(3), 321-336.

Ma, X., Stewin, L. L. \& Mah, D. (2001) Bullying in school: nature, effects and remedies, Research Papers in Education, 6(3), 247-270.

Mac an Ghaill, M. (1994) The making of men: masculinities, sexualities and schooling (Buckingham, Open University Press).

Maines, B. \& Robinson, G. (1992) The no-blame approach (Bristol, Lame).

Mills, M. (2001) Challenging violence in schools: an issue of masculinities (Buckingham, Open University Press).

Mirza, H. S. (2009) Race, gender and educational desire: why black women succeed and fail (London, Routledge).

Olweus, D. (1991) Bully/victim problems among schoolchildren: basic facts and effects of a school based intervention program, in: D. J. Pepler \& K. H. Rubin (Eds) The development and treatment of childhood aggression (Hillsdale, NJ, Erlbaum), 411-448.

Olweus, D. (1993) Bullying in schools: what we know and what we can do (Oxford, Blackwell).

Olweus, D. (1999) Bullying prevention program (Boulder, CO, University of Colorado).

O’Neill, D. \& Morgan, M. (2001) Pragmatic post-structuralism (I): participant observation and discourse in evaluating violence intervention, fournal of Community $\&$ Applied Social Psychology, 11(4), 263-275. 
Osler, A. and Vincent, K. (2003) Girls and exclusion: rethinking the agenda (London, RoutledgeFalmer).

Owens, L., Shute, R. \& Slee, P. (2000a) 'Guess what I just heard!': indirect aggression among teenage girls in Australia, Aggressive Behaviour, 26(1), 67-83.

Owens, L., Slee, P. \& Shute, R. (2000b) 'It hurts a hell of a lot ...' The effects of indirect aggression on teenage girls, School Psychology International, 21(4), 359-376.

Paechter, C. (1998) Educating the other: gender, power and schooling (London, Routledge).

Palmer, S. (2006) Toxic childhood: how the modern world is damaging our children and what we can do about it (London, Orion).

Pascoe, C. J. (2007) Dude, you're a fag: masculinity and sexuality in high school (Berkeley, CA, University of California Press).

Phoenix, A. \& Pattynama, P. (2006) Editorial. Intersectionality, International fournal of Women's Studies, 13(3), 187-192.

Reay, D. (2002) Shaun's story: troubling discourses of white working class masculinities, Gender and Education, 14(3), 221-234.

Renold, E. (2002) 'Presumed innocence': (hetero)sexual, homophobic and heterosexist harassment amongst primary school girls and boys, Childhood, 9(4), 415-433.

Renold, E. (2005) Girls, boys and junior sexualities: exploring children's gender and sexual relations in the primary school (London, RoutledgeFalmer).

Renold, E. \& Murphy, D. (2007) Working with girls, in: K. Myers with S. Adler, D. Leonard \& H. Taylor (Eds) Genderwatch: still watching (Stoke on Trent, Trentham Books).

Rigby, K. (1998) Gender and bullying in schools, in: P. T. Slee \& K. Rigby (Eds) Peer relations amongst children: current issues and future directions (London, Routledge), 48-59.

Ringrose, J. (2006) A new universal mean girl: examining the discursive construction and social regulation of a new feminine pathology, Feminism and Psychology, 16(4), 405-424.

Ringrose, J. (2007a) Troubling agency and 'choice': a psycho-social analysis of students' negotiations of Black feminist 'intersectionality' discourses in Women's Studies, Women's Studies International Forum, 30(3), 264-278.

Ringrose, J. (2007b) Rethinking white resistance: exploring the discursive practices and psychical negotiations of 'whiteness' in feminist, anti-racist education, Race, Ethnicity and Education, $10(3), 321-342$.

Ringrose, J. (2008a) 'Just be friends': exposing the limits of educational bully discourses for understanding teen girls' heterosexualized friendships and conflicts, British fournal of Sociology of Education, 29(5), 509-522.

Ringrose, J. (2008b) 'Every time she bends over she pulls up her thong': teen girls negotiating discourses of competitive, heterosexualized aggression, Girlhood Studies, 1(1), 33-59.

Ringrose, J. (forthcoming, 2009) Beyond discourse?: using Deleuze and Guattar's schizoanalysis to explore heterosexually striated space, affective assemblages, and lines of flight online and at school, Educational Philosophy \& Theory.

Ringrose, J. \& Renold, R. (2008) Fantasy, regulation and rupture: girls' negotiating heteronormative femininity and heterosexualized violences, Paper presented at the American Educational Research Association Conference, New York, March 2008.

Ringrose, J. \& Walkerdine, V. (2007) Exploring some contemporary dilemmas of femininity and girlhood in the west, in: C. A. Mitchell \& J. Reid-Walsh (Eds) Girl culture: an encylopedia (Westport, CT, Greenwood Press).

Ringrose, J. \& Walkerdine, V. (2008) Regulating the abject: the TV make-over as site of neo-liberal reinvention toward bourgeois femininity, Feminist Media Studies, 8(3), 227-246.

Salmivalli, C., Karhunen, J. \& Lagerspetz, K. M. J. (1996) How do the victims respond to bullying? Aggressive Behaviour, 22(2), 99-109.

Shute, R.H., Owens, L. \& Slee, P. (2002) 'You just stare at them and give them daggers': nonverbal expressions of aggression in teenage girls, International fournal of Adolescence and Youth, 10, 353-372. 
Skeggs, B. (2005) The making of class and gender through visualizing moral subject formation, Sociology, 39(5), 965-982.

Skelton, C. (2001) Schooling the boys (Buckingham, Open University Press).

Smith, P. K. \& Brain, P. (2000) Bullying in school: lessons from two decades of research, Aggressive Behavior, 26, 1-9.

Sunnari, V., Kangasvuo, J. \& Heikkinen, M. (2002) Gendered and sexualised violence in educational environments (Oulu, Finland, Oulu University Press).

Telegraph (2003, March 23) Tributes flood in for Jade Goody, Telegraph. Available online at: http:/ /www.telegraph.co.uk/news/newstopics/celebritynews/jade-goody/5036096/Tributes-flood-infor-Jade-Goody.html (accessed 25 May 2009).

Tolman, D. (2002) Dilemmas of desire: teenage girls talk about sexual desire (Harvard University Press).

Walkerdine, V. (1991) Schoolgirl fictions (London, Verso).

Walkerdine, V. (1997) Daddy's girl (London, Verso).

Walton, G. (2005) Bullying widespread: a critical analysis of research and public discourse on bullying, fournal of School Violence, 4(1), 91-118.

Watkins, C., Mauthner, M., Hewitt, R., Epstein, D. \& Leonard, D. (2007) School violences, school differences and school discourses, British Educational Research fournal, 33(1), 61-74.

Wolke, D., Woods, S., Schulz, H. \& Stanford, K. (2001) Bullying and victimisation of primary school children in South England and South Germany: prevalence and school factors, British Fournal of Psychology, 92, 673-696.

Woods, S., \& Wolke, D. (2003) Does the content of anti-bullying policies inform us about the prevalence of direct and relational bullying behaviour in primary schools? Educational Psychology, 23(2), 381-402.

Youdell, D. (2006) Impossible bodies, impossible selves: exclusions and student subjectivities (London, Springer).

Youdell, D. (forthcoming) Performativity: making the subjects of education, in: L., Zeus (Ed.) Handbook of cultural politics in education (Thousand Oaks, CA, Sage). 